\title{
Maskulinitas dan Praktik Tangkap Lepas dalam Memancing: Sebuah kajian terhadap Sportfishing
}

\author{
Gesang Manggala Nugraha Putra \\ Departemen Sastra Inggris, Fakultas Ilmu Budaya, \\ Universitas Airlangga, Jl. Dharmawangsa Dalam \\ Selatan, Surabaya, Indonesia \\ E-mail: gesang.m@gmail.com
}

\begin{abstract}
The absence of legal regulation in fishing activities has brought Indonesian waters to a serious degradation, especially in the population of game fish. The most reasonable solution to this problem is performing Catch and Release (CnR). However, very little has been explored regarding the activity of fishing and CnR in Indonesia. This study aims to identify masculinity traits in sportfishing as a masculine act. Furthermore, the result will hopefully be useful in designing an effective campaign for CnR. This study employs qualitative method to discover how sportfishing is produced and consumed, formulate the meaning of sportfishing to Indonesian anglers, and identify masculinity traits in the enactment and involvement of this activity. The study concludes that sportfishing is the new hegemonic masculinity, replacing the previous conventional fishing. It is a masculine bloc that inherits classic masculine traits and combines them with aspects of femininity, resulting in a new adaptive model of masculinity that sustains the patriarchal dominance toward subordinate masculinity and women.
\end{abstract}

Keywords: sportfishing, hegemonic masculinity, catch and release

\section{Pendahuluan}

Penelitian ini merupakan sebuah kajian budaya yang dilakukan dengan maksud mengidentifikasi aspek-aspek sosiokultural, terutama maskulinitas, dari para pemancing yang mempengaruhi pandangan mereka terhadap tangkap-lepas. Konstruksi maskulinitas yang terinternalisasi dalam diri pemancing dipandang penting karena berdasarkan data yang diambil dari salah satu komunitas pemancing, perbandingan antara jumlah pemancing berjenis kelamin laki-laki dan berjenis kelamin perempuan adalah kurang lebih 200:1. Jadi, recreational fishing adalah kegiatan yang didominasi oleh laki-laki (Aas 2002, p.260).

Lebih lanjut lagi, penelitian ini akan difokuskan pada pemancing yang tergabung dalam tiga komunitas memancing di Indonesia: Kaskus Fishing Community, Castinger Community dan Surabaya Fishing Club. Dua di antara komunitas memancing tersebut berpusat di Surabaya, Jawa Timur. Jawa Timur dipilih karena merupakan salah satu dari provinsi terbesar di Indonesia yang lokasi geografisnya berada di tengah antara Indonesia bagian barat dan timur. Perairan Indonesia barat dan timur adalah wilayah Indonesia yang terkenal dengan potensi wisata memancingnya. Alasan lain dalam pemilihan Jawa Timur sebagai lokasi penelitian adalah karena banyaknya pemancing olah raga terkemuka di Indonesia yang berasal dari daerah ini. Memancing umumnya dilakukan untuk dua tujuan utama: menangkap ikan dan rekreasi. Sebagian besar pemancing melakukan kegiatan ini untuk mencapai dua tujuan tersebut. Jadi selain melepas kepenatan, membawa pulang ikan hasil tangkapan memberikan kepuasan tersendiri pada hampir semua 
pemancing (Schultz 2010, p.2). Namun sekarang muncul fenomena yang menarik di kalangan para pemancing, yaitu praktik catch and release, atau tangkap-lepas. Tangkap-lepas adalah sebuah praktik dimana pemancing akan melepas kembali ikan yang mereka tangkap atas alasan konservasi. Ikan yang dilepaskan kembali diharapkan dapat terus hidup sehingga tidak mengurangi populasi ikan dan mengganggu keseimbangan ekosistem.

Terkait dengan tujuan konservasi, beberapa sumber menunjukkan bahwa praktik tangkaplepas memiliki andil besar dalam mempertahankan populasi ikan. Studi yang dilakukan oleh Reiss, Reiss, dan Reiss tahun 2003, misalnya, membuktikan bahwa praktik tangkap-lepas, jika dilakukan dengan benar, akan secara signifikan menjaga populasi ikan (p.9). Atas bukti dari hasil penelitianpenelitian tersebut, beberapa negara (dan wilayah yuridis lainnya) sudah menetapkan, dan/atau memperketat hukum terkait praktik tangkap-lepas. Negara bagian Florida di Amerika Serikat, misalnya, menetapkan hukum yang mengatur kuantitas ikan yang boleh dibawa oleh pemancing, baik berdasarkan spesies, ukuran, maupun daerah penangkapannya.

Di Indonesia sendiri, praktik tangkap-lepas dalam recreational fishing belum diatur secara hukum. Hukum yang mengatur tentang perikanan dan kelautan hanya berkutat pada commercial fishing yang dilakukan oleh nelayan sebagai usaha mencari nafkah ataupun tujuan-tujuan komersil lainnya. Sehingga, pemancing rekreasi bebas melakukan apa saja yang mereka inginkan asalkan tidak melanggar ketentuan-ketentuan umum tentang perairan dan perikanan. Meski dengan kenyataan tersebut, ada beberapa pemancing individual, kelompok pemancing, maupun penyedia layanan trip memancing yang secara sukarela menerapkan tangkap-lepas, baik di laut maupun air tawar. Namun, jika dibandingkan dengan jumlah keseluruhan pemancing rekreasional, perbandingannya masih sangat jauh.

Ketiadaan hukum legal dan kurangnya partisipasi pemancing rekreasional terkait praktik tangkap-lepas merupakan suatu fakta yang sangat disayangkan mengingat potensi laut Indonesia yang luar biasa. Perairan Indonesia termasuk dalam the coral triangle. Bersama dengan perairan utara Australia, Papua, dan Filipina, laut Indonesia merupakan rumah bagi lebih dari 3000 spesies biota laut yang hidup di dekat pantai, belum termasuk biota laut dalam dan ikan-ikan pelagis yang hidup jauh dari pantai. Laut Indonesia juga merupakan tempat tinggal bagi lebih dari $37 \%$ spesies ikan dunia (Timmers 2010). Selain itu, beberapa spesies game fish atau sport fish (ikan target untuk perlombaan dan pencatatan rekor) air laut populer yang tercatat dalam IGFA (International Game Fish Association) ada di Indonesia. Jika kelestarian populasi ikan tidak dijaga, melalui praktik tangkap- lepas misalnya, maka potensi perairan Indonesia dipastikan akan menurun.

Untuk menjawab tantangan tersebut, penelitian ini bermaksud mengidentifikasi unsur- unsur apa saja yang mungkin mempengaruhi kemauan pemancing untuk mempraktikkan tangkap-lepas, khususnya dalam sportfishing. Salah satu unsur yang penting disini adalah maskulinitas. Maskulinitas menjadi penting karena seperti dijelaskan diawal, kegiatan memancing didominasi oleh kaum lelaki. Penelitian ini dilakukan untuk mengidentifikasi atribut-atribut maskulinitas yang terinternalisasi dalam kegiatan sportfishing. 
Maskulinitas adalah sesuatu yang cair, dan oleh karena itu, atribut-aribut penyertanya juga mungkin berbeda di tempat dan waktu yang berbeda. Namun penelitian ini akan mengadopsi atribut-atribut maskulinitas sebagaimana dikemukakan oleh Ian M. Harris dalam bukunya yang berjudul Messages Men Hear (2005). Harris memformulasikan 24 atribut maskulinitas dan kemudian merangkumnya dalam 5 kategori, yaitu: standard bearers, workers, lovers, bosses, dan rugged individuals (yang selanjutnya akan disebut sebagai penopang, pekerja, kekasih, bos, dan sosok keras). Gagasan Harris sengaja dipilih untuk penelitian ini karena atribut-atribut yang diusulkannya tidak hanya mencakup peran maskulinitas tradisional tetapi bahkan unsur-unsur yang diasosiasikan dengan femininitas. Luasnya cakupan ini dimaksudkan agar penelitian ini dapat membedah sportfishing dengan lebih komprehensif. Sportfishing menjadi sebuah acuan yang penting karena, sebagaimana akan dijelaskan kemudian, merupakan kegiatan yang berorientasi pada proses. Hal inilah yang menjadi salah satu pembeda utama antara sportfishing dengan tehnik memancing konvensional. Orientasi pada proses ini jugalah yang membuat sportfishing menjadi penting dalam kaitannya dengan praktik tangkap-lepas. Pelaku sportfishing akan lebih berfokus pada kegiatan memancing mereka sebagai sebuah ajang unjuk maskulinitas daripada membawa pulang ikan hasil tangkapan.

\section{Metode}

Penelitian ini akan difokuskan pada kegiatan memancing, khususnya sportfishing. Belum ada literatur yang membahas sportfishing secara spesifik, dan oleh karena itu belum memiliki definisi teoretis. Meski penelitian ini tidak ditujukan untuk menemukan definisi sportfishing, namun pembatasan tetap diperlukan untuk mempertahankan fokus penelitian. Berdasarkan hasil wawancara yang dilakukan oleh peneliti, sportfishing secara sederhana digambarkan sebagai teknik-teknik memancing yang dibedakan dengan teknik memancing konvensional dalam hal keahlian teknis, kemampuan fisik, dan kompetisinya (pembatasan ini akan dibahas lebih lanjut dalam bagian selanjutnya). Tujuan dari penelitian ini adalah untuk mengidentifikasi 24 atributatribut maskulinitas, sebagaimana dikemukakan oleh Harris, dalam sportfishing. Identifikasi tersebut dilakukan melalui:

(1) pengamatan partisipatif, baik dalam kegiatan memancing maupun forum-forum di dunia maya; dan (2) wawancara dengan para narasumber. Narasumber dan responden diambil dari anggota komunitas memancing, yaitu Kaskus Fishing Community, Castinger Community dan Surabaya Fishing Club. Selain melakukan pertemuan rutin dan kegiatan memancing bersama, ketiga komunitas tersebut juga aktif berkomunikasi melalui dunia maya, baik lewat forum maupun jejaring sosial seperti facebook. Komunitas-komunitas tersebut dipilih karena memiliki anggota di beberapa wilayah Indonesia. Ini menjadi penting agar hasil penelitian ini dapat cukup mewakili budaya-budaya lokal yang berbeda yang mungkin mempengaruhi pandangan pemancing dari daerah tersebut.

Penelitian ini dilakukan dengan pendekatan kualitatif. Pendekatan kualitatif diaplikasikan 
untuk mendefinisikan sportfishing, mengidentifikasi konstruksi maskulinitas di kalangan para pemancing olah raga dan bagaimana mereka memandang praktik tangkap lepas. Pendekatan kualitatif sesuai untuk menjawab pertanyaan-pertanyaan tersebut karena pendekatan kualitatif memang ditujukan untuk: memperoleh pemahaman makna, menemukan pola hubungan interaktif, dan menggambarkan realitas yang kompleks (Sugiyono 2011, p. 14).

Jenis data yang digunakan dalam penelitian ini adalah data primer dan sekunder. Data primer dalam penelitian ini berupa hasil survei dari para responden, komentar-komentar di jejaring sosial dan forum online yang terkait dengan komunitas- komunitas yang diamati, dan wawancara dengan para narasumber. Sedangkan data sekunder, yang diperoleh dari pencatatan pihak lain, dalam penelitian ini adalah berupa teks lengkap, yang terdapat dalam buku, artikel, jurnal, dan/atau data online dari Internet yang relevan dengan topik bahasan.

Data kualitatif dalam penelitian diperoleh dengan dua metode. Metode yang pertama adalah pengamatan terlibat. Untuk melakukan pengamatan terlibat ini, peneliti ikut serta dalam berbagai kegiatan yang diadakan oleh ketiga komunitas yang diamati, baik kegiatan memancing bersama maupun pertemuan-pertemuan yang dilakukan oleh para anggotanya. Selain itu, peneliti juga memantau dan ikut serta dalam aktifitas komunitas-komunitas tersebut di dunia maya, baik melalui jejaring sosial seperti facebook maupun forum online di situs kaskus.co.id. Komentar-komentar yang ditulis dalam situs-situs ini juga akan menjadi data primer. Pengamatan terlibat ini dilakukan mulai tahun 2011 hingga saat penelitian ini dibuat. Metode kedua adalah wawancara mendalam.Wawancara dilakukan untuk mengetahui motif, tujuan, dan opini para narasumber terhadap kegiatan memancing, sportfishing dan tangkap-lepas, yang tentunya tidak mungkin diketahui hanya melalui kuesioner. Pemilihan narasumber untuk wawancara dilakukan dengan metode purposive sampling.

Kriteria-kriteria yang menjadi pertimbangan dalam pemilihan narasumber adalah, usia, jumlah keluarga yang menjadi tanggungan, jumlah penghasilan, lama terlibat dalam kegiatan memancing, dan peran dalam komunitas memancing. Wawancara dilakukan selama periode Februari hingga Juni 2012. Selama periode tersebut, ada 15 narasumber yang diwawancarai. Dua belas narasumber pertama sebenarnya sudah menunjukkan kejenuhan jawaban, namun peneliti masih menambah narasumber dengan anggapan bahwa mungkin akan muncul inkonsistensi. Namun hingga pada narasumber ke 15, tidak ditemukan adanya inkonsistensi yang signifikan, dan oleh karena itu, wawancara dihentikan setelah narasumber ke 15. Seluruh narasumber adalah anggota dan/atau pengurus Kaskus Fishing Community, Surabaya Fishing Club, dan Castinger Community. Seluruh narasumber, responden, dan penulis komentar dalam situs telah dimintai persetujuan sebelum namanya dicantumkan dalam penelitian ini. Narasumber, responden, dan/atau penulis komentar yang tidak bersedia disebutkan namanya akan diidentifikasi dengan sebutan narasumber, responden, anggota, atau pengguna.

Data primer yang diperoleh dari hasil pengamatan dan wawancara pertama kali akan 
dianalisa guna mengidentifikasi memancing sebagai suatu kegiatan yang maskulin. Selanjutnya, data tersebut akan dianalisa lebih lanjut untuk mencari tahu pandangan para responden dan narasumber terhadap sportfishing. Hal ini dilakukan untuk menentukan batasan mengenai sportfishing itu sendiri. Setelah itu, hasil tersebut juga akan dianalisa untuk ketigakalinya guna mencari tahu jejak-jejak atribut maskulinitas yang muncul. Kedua langkah analisa ini dilakukan secara kualitatif dengan menghubungkan data primer tersebut dengan data sekunder yang diperoleh dari sumber-sumber literatur untuk memperkuat argumen yang dibuat dalam penelitian ini.

\section{Hasil dan Pembahasan}

\section{Produksi dan Konsumsi Memancing yang Maskulin}

Seperti halnya banyak kegiatan lain yang dikategorikan sebagai hobi, memancing juga telah menjadi sebuah industri. Namun analoginya tidak berhenti sampai disitu, sama juga seperti hobihobi lain yang dikategorikan sebagai olah raga, industri memancing adalah industri yang dirancang dengan kaum lelaki sebagai pasar potensialnya. Para produsen dalam industri ini memasarkan produknya dengan mengaitkannya kepada konsep- konsep maskulinitas seperti kontrol, dominasi, keahlian teknis (Adkins 2010, p. 21), dan terutama, agresi (Lippa 2005, p. 15). Hal ini dapat diamati dengan cara melihat produk-produk perlengkapan memancing yang mereka pasarkan.

Shimano, sebuah pabrikan peralatan memancing ternama dari Jepang, menyebut produk baitcast reel (sebuah varian produk penggulung senar) kelas premiumnya sebagai "weapon of choice for fresh and saltwater anglers". Selain Shimano, pabrikan alat pancing ternama dari Cina, Crony, menamai tipe produk jorannya 'Man's Toys' dan 'Aggress'. Selain itu, ada pula pabrikan alat pancing yang sangat terkemuka di dunia, Rapala. Dalam katalognya tahun 2012, pabrikan asal Finlandia ini mendeskripsikan pelanggannya sebagai 'weekend warriors'. Penyebutan-penyebutan tersebut sangat kaya akan unsurunsur maskulinitas sebagaimana dikemukakan oleh Adkins dan Lippa diatas.

Memang benar bahwa ada pabrikan- pabrikan yang membuat dan memasarkan produk perlengkapan memancing yang dirancang khusus untuk konsumen perempuan. Ross, sebuah pabrikan peralatan memancing fly fishing kelas menengah-atas dari Amerika Serikat, meluncurkan lini produk joran khusus untuk konsumsi perempuan yang diberi label Diamond Series. Joran ini dirancang dengan diameter gagang yang 25\% lebih kecil daripada joran kebanyakan dan hadir dengan warna burgundy. Selain itu, logo gambar bunga lili yang menjadi ciri khas joran Ross, diberi tambahan aksen berlian imitasi di tengahnya. Dalam katalog produknya, Ross mendeskripsikan joran Diamond Series ini dengan kata-kata "pulasan khusus dan kilaunya membuat seri ini menjadi penawaran yang sangat unik bagi pemancing perempuan yang memancing dengan gaya".

Selain Ross, pabrikan alat pancing kelas menengah-atas lain yang juga berasal dari Amerika Serikat, St. Croix, juga memiliki lini produk joran yang didesain untuk konsumen perempuan. Lini produk yang diberi nama Avid Pearl Series tersebut juga dirancang dengan diameter yang lebih kecil dan warna ungu bersemu pink. Dilabeli sebagai joran paling mutakhir yang pernah dibuat 
untuk perempuan, Avid Pearl Series dideskripsikan dengan istilah "gorgeous".

Selain dari segi desain dan warna, ada hal lain yang menjadi ciri khas produk alat pancing khusus perempuan, yaitu kualitas yang lebih rendah dan harga yang lebih murah jika dibandingkan dengan produk alat pancing umumnya; atau dalam bahasan ini, alat pancing untuk laki-laki. Avid Pearl Series misalnya, yang dipasarkan dengan harga antara \$180-\$200, kalah jauh dengan seri joran keluaran St. Croix yang lain yang dijual dengan harga dua kali lipat; dan dalam hal alat pancing, harga selalu mencerminkan kualitas. Jadi, produsen masih sangat menitikberatkan produknya pada konsumen laki-laki.

Tidak hanya dari segi produk, istilah-istilah yang digunakan dalam kegiatan memancing juga sangat kental dengan unsur-unsur maskulinitas. Pemancing kerap kali memakai istilah "pertarungan" untuk mendeskripsikan periode dari saat ikan memakan umpan hingga ikan tersebut berhasil dinaikkan (landed). Momen tersebut diromantisasi sebagai ajang adu kekuatan dan keahlian antara pemancing dan ikan. Lebih lanjut lagi, pemancing yang berhasil menaikkan ikan, baik keatas kapal maupun ke darat, sering dideskripsikan dengan istilah "memenangkan pertarungan" dan/atau "mengalahkan ikan". Disisi lain, ikan yang berhasil dinaikkan digambarkan dengan istilah "menyerah" dan/atau "kalah". Dalam salah satu forum memancing, salah seorang pengguna mendeskripsikan rencana memancingnya dengan kata-kata "gua bantai neh betok ama babon beunteur nya".

Penggunaan kata-kata seperti ini tidak hanya ditemui dalam praktik memancing sehari-hari tetapi juga pada narasi acara-acara televisi tentang memancing. Ada dua acara memancing yang disiarkan di televisi nasional di Indonesia, yaitu Mancing Mania yang disiarkan di Trans7 dan Mata Pancing yang disiarkan di MNC TV. Para narator dalam acara-acara televisi tersebut menggunakan bahasa-bahasa seperti "ikan pun akhirnya takluk di tangan pemancing asal Jakarta ini" atau "fight berlangsung cukup lama, namun akhirnya pemancing asal Berau ini berhasil memenangkan pertarungan". Pembawa acara dalam acara tersebut juga mendeskripsikan ikan sebagai berjender perempuan. Dalam salah satu episode Mancing Mania, pembawa acaranya mendeskripsikan ikan talang-talang (Chorinemus tala), ikan layaran (Istiophorus platypterus), ikan sappan (Tor tambroides), dan beberapa spesies ikan lain sebagai ikan yang "cantik", sebuah istilah yang dalam Kamus Besar Bahasa Indonesia diasosiasikan dengan perempuan. Dari kecenderungankecenderungan diatas, maka dapat disimpulkan bahwa proses memancing dapat dianalogikan sebagai sebuah proses unjuk kebolehan pemancing yang maskulin untuk menaklukkan ikan yang feminin.

Alur produksi-konsumsi menjadi signifikan karena sebagai sebuah praktik, proses tersebut memperkuat posisi memancing sebagai kegiatan yang maskulin. Dari sisi produksi, produsen seolah menegaskan gagasan yang disinggung juga oleh Connell (1995), mengenai maskulinitas. Maskulinitas, menurutnya, adalah serangkaian praktik yang berdampak mengsubordinasi perempuan. Desain produk dan kualitas alat pancing untuk perempuan mengukuhkan bahwa dalam hal memancing, lelaki seharusnya lebih baik dari perempuan. 
Para pemancing juga mengkonsumsi kegiatan tersebut sebagai suatu kesempatan untuk menunjukkan agresi dan dominasi mereka sebagai sosok yang maskulin. Lebih lanjut lagi, pola konsumsi menjadi penting dalam pembahasan penelitian ini karena konstruksi sosial semacam inilah yang membentuk persepsi kebanyakan orang tentang jender dan peran jender (Lippa 2005, p. 66). Selain produksi dan konsumsi, kemampuan fisik juga menjadi penting dalam diskursus memancing sebagai kegiatan maskulin. Pokok bahasan selanjutnya akan menitikberatkan pada praktik memancing sebagai suatu olahraga, dan bagaimana kemampuan fisik pelakunya menjadi poin penting dalam hubungannya dengan maskulinitas.

\section{Sportfishing: Sebuah Olah Raga}

Sebagaimana disebutkan dalam tiga penelitian berbeda yang dilakukan oleh Bishop dan Samples (1979), Beehler et.al. (2001), dan Cooke dan Cowx (2005), batasan-batasan antara sportfishing dan commercial fishing seringkali tumpang tindih. Bahkan banyak yang berpendapat bahwa memancing, secara umum, adalah sebuah olah raga.Hal ini dikarenakan adanya unsur aplikasi kemampuan fisik, teknis, dan kompetisi dalam memancing.

Karena adanya tumpang tindih istilah dan perbedaan pendapat tersebut, maka sebelum beranjak lebih jauh, penelitian ini berusaha memulainya dengan menjaring opini tentang apa sebenarnya sportfishing itu. Opini diperoleh dari proses wawancara dengan para narasumber. Sebanyak 9 orang narasumber berpendapat bahwa tidak semua kegiatan memancing dapat disebut sebagai olah raga. Menurut mereka, hanya ada beberapa teknik memancing saja yang dapat disebut sebagai olah raga, dan oleh karena itu, termasuk dalam kategori sportfishing. Meski ada sedikit variasi yang muncul dalam wawancara, namun secara umum, mereka sependapat bahwa teknikteknik memancing berikutlah yang dapat digolongkan sebagai sportfishing: casting, popping, jigging, dan fly fishing. 
Keempat teknik yang digolongkan sebagai sportfishing diatas memiliki beberapa kesamaan dimana masing-masing kesamaan tersebutlah yang menjadikannya layak dimasukkan dalam kategori tersebut. Yang pertama adalah jenis umpan yang digunakan.Keempat teknik tersebut semuanya menggunakan umpan buatan untuk menarik ikan. Penggunaan umpan buatan ini membutuhkan keahlian khusus yang harus dimiliki pemancing: keahlian untuk memainkan gerakan umpan buatan sehingga ikan target akan mengira umpan tersebut sebagai makanan alaminya dan memakannya.

Kesamaan yang kedua adalah perlunya tenaga dan stamina lebih untuk mengaplikasikan keempat teknik diatas. Tenaga dan stamina yang dimaksud disini tidak hanya diperlukan saat ikan sudah terkail, tetapi juga saat sebelum ikan memakan umpan. Dalam teknik memancing konvensional, umpan hanya perlu dilemparkan ke titik sasaran dan kemudian didiamkan begitu saja sambil menunggu. Ikan akan memakan umpan tersebut karena memang itu adalah makanan alaminya. Sebaliknya, keempat teknik diatas mengharuskan pemancing untuk terus-menerus melempar dan menarik umpan. Hal ini dikarenakan jika umpan buatan yang dipakai untuk teknik ini tidak digerakkan dan dimainkan, umpan tersebut hanya akan menjadi plastik atau kayu yang mengapung diam di permukaan atau seonggok logam yang tergeletak di dasar air, dan ikan tidak akan memakannya. Proses lempar-tarik terus menerus inilah yang membutuhkan tenaga dan stamina ekstra dari pemancing.

Namun ada satu aspek lagi dari olah raga yang sepertinya luput dari perhatian para narasumber, atau setidaknya tidak muncul dalam wawancara, yaitu kompetisi. Salah satu aspek penanda dari olah raga adalah kompetisi (Coakley 2009, p. 6). Sebuah kegiatan dapat dikatakan sebagai olah raga jika ada unsur persaingan di dalamnya. Memancing sangat kental dengan unsur ini. Tidak hanya dalam perlombaan-perlombaan memancing, setiap pemancing memiliki kecenderungan untuk menjadi yang teratas dengan menangkap ikan yang terbesar. Semakin besar ikannya, semakin tinggi prestasinya, semakin meningkat pula statusnya di kalangan sesama pemancing. Keahlian teknis, kemampuan fisik, dan kecenderungan berkompetisi inilah yang menjadikan sportfishing sebagai kegiatan olahraga yang maskulin.

Konsepsi memancing sebagai sebuah olahraga memiliki peran penting dalam simbolisme maskulinitas. Beberapa peneliti yang juga memproposisikan gagasan ini adalah Pronger (1990), Connell (1995), dan Adams, Anderson dan McCormack (2010). Mereka mengemukakan bahwa olahraga digunakan sebagai alat untuk menguatkan dominasi maskulinitas. Namun tidak hanya itu, beberapa peneliti lain menegaskan bahwa partisipasi perempuan harus dihilangkan agar penguatan ini dapat bekerja optimal (Bryson 1987, dan Bourdieu 2001). Konsepsi ini, bersamaan dengan alur produksi-konsumsi, bekerja saling melengkapi dalam menguatkan dominasi laki-laki terhadap perempuan dalam dua level. Di level pertama, konsepsi memancing sebagai olahraga menyediakan jalur bagi laki-laki untuk menguatkan maskulinitasnya melalui tindakan memancing. Di level kedua, alur produksi-konsumsi bekerja mengeksklusifkan jalur ini 
khusus (atau setidaknya memberi lebih banyak ruang) untuk laki-laki.

\section{Atribut-Atribut Maskulinitas dalam Sportfishing}

Penelitian ini mengelompokkan ke-24 pesan maskulinitas yang dikemukakan oleh Harris menjadi empat kategori besar yang dapat ditelusuri dalam kegiatan sportfishing, yaitu unjuk keahlian, kemampuan fisik, pemberi nafkah dan pelindung. Masing-masing kategori beserta pesanpesan yang terkandung didalamnya dirangkum dalam tabel 1 berikut.

Tabel 1. Atribut Maskulinitas dalam Sportfishing

\begin{tabular}{|l|l|}
\hline Kategori & Atribut Maskulinitas \\
\hline Unjuk keahlian & $\begin{array}{l}\text { Pelajar Teknisi Etika kerja } \\
\text { Jadi yang terbaik Pencapaian Mandiri Hukum } \\
\text { Kendali } \\
\text { Penggoda }\end{array}$ \\
\hline Kemampuan Fisik & $\begin{array}{l}\text { Olahragawan Petualang Pria Tangguh } \\
\text { Tahan banting Pemberontak } \\
\text { Superman }\end{array}$ \\
\hline Pemberi Nafkah & $\begin{array}{l}\text { Jadi seperti ayah Pencari nafkah Suami setia Uang } \\
\text { Pemelihara }\end{array}$ \\
\hline Pelindung & $\begin{array}{l}\text { Pecinta alam Dermawan Presiden } \\
\text { Ksatria }\end{array}$ \\
\hline
\end{tabular}

Ada beberapa temuan menarik yang dapat dibahas lebih lanjut dari penelusuran atributatribut maskulinitas diatas. Salah satunya adalah ketidakmunculan atribut superman. Atribut ini tidak muncul karena pemancing menyadari betul bahwa ada faktor-faktor yang berada diluar kuasa mereka, dan hal terbaik yang bisa mereka lakukan hanyalah memprediksinya. Dan disinilah keahlian, sekali lagi, memainkan peranan penting. Serangkaian pengetahuan yang dimiliki oleh pemancing akan menentukan keberhasilannya dalam memprediksi. pengaruh faktor-faktor diatas terhadap keberhasilannya memancing. Jadi, keahlian tetap merupakan aspek yang sangat penting dalam sportfishing yang maskulin.

Ketidakmunculan atribut superman disini juga menyediakan petunjuk bahwa konstruksi maskulinitas di Indonesia berbeda dengan konstruksi Barat, termasuk juga atribut-atribut yang menyertainya. Selain itu, ada pula perpaduan antara dua konsepsi maskulinitas yang berbeda yang muncul pada kategori pemelihara'. Kategori ini menjadi menarik karena dua hal: (1) berdasarkan penelitian, ternyata tidak semua pesan maskulinitas yang diusulkan oleh Harris terinternalisasi dalam kegiatan sportfishing, dan (2) bahwa faktor keluarga masih memegang peranan penting dalam kegiatan ini. Hal ini membuktikan bahwa dalam konteks sportfishing-pun, identitas gender seorang lelaki masih dikaitkan dengan perannya dalam hubungan dengan orang lain, terutama keluarga. Pendapat ini senada dengan hasil penelitian Verma dan Mahendra tentang konstruksi 
maskulinitas di India (2004). Selain itu, nosi ini juga didukung oleh pendapat Nisbett (2003) bahwa budaya Asia memang mendorong terbentuknya ikatan keluarga yang kuat, dan bahwa menjaga ikatan itu merupakan sebuah kewajiban.

Namun disisi lain, ini berlawanan dengan argumen Baumeister dan Sommer. Mereka berpendapat bahwa, tidak seperti perempuan, lelaki cenderung mengkonsepsi diri mereka dalam kaitannya dengan kelompok-kelompok sosial dan hubungan-hubungan hierarkis (dalam Lippa 2005, p. 42). Cara pandang seperti ini lebih terlihat dalam pemanfaatan sportfishing sebagai ajang unjuk keahlian diantara sesama pemancing. Dengan kata lain, disatu sisi, sportfishing menunjukkan kepedulian akan hubungan emosional orang per orang, sedangkan disisi lain menekankan pentingnya status di kalangan komunitas pemancing yang hierarkis. Jadi, sportfishing adalah perpaduan dari dua maskulinitas yang berbeda.

Hal ini sejalan dengan konsep maskulinitas ganda yang dikemukakan oleh Lecture dan Connell (2000). Temuan ini juga memperkuat pendapat $\mathrm{Ng}$ et al. bahwa representasi maskulinitas, dan atribut- atribut yang menyertainya, di Asia berbeda dengan di Euro-Amerika. Ng et al. bahkan menemukan bahwa diantara negara-negara Asia, ada persepsi yang berbeda mengenai bagaimana menjadi maskulin (2008). Melalui temuan ini, nyatalah bahwa, seperti halnya negara-negara yang menjadi lokasi penelitian Ng et al., Indonesia memiliki konsepsi maskulinitasnya sendiri, khususnya dalam praktik sosial yang disebut sportfishing.

Hal yang menarik kedua adalah kasus yang dialami oleh Bayu yang mengalihkan ketidakmampuannya untuk memancing di tengah laut menjadi banyak pencapaian-pencapaian lain di ranah air tawar. Bayu menunjukkan bahwa dirinya adalah pemancing air tawar yang tangguh, dan ia mendapat pengakuan dari rekan sesama pemancing untuk pencapaiannya itu. Kesimpulan yang dapat ditarik dari kasus ini adalah b2ahwa saat seorang pemancing gagal memenuhi salah satu atribut penting, akan ada kecenderungan untuk memperkuat atribut yang lain. Kasus Bayu disini, menunjukkan bahwa saat ia gagal menunjukkan atribut pria tangguh dalam dirinya, ia mengalihkan kemampuannya untuk memperkuat atribut-atribut lain yang masuk dalam kategori keahlian. Pengalihan atribut ini dilakukan agar pemancing tetap dapat menjaga, bahkan meningkatnya statusnya dalam kalangan sesama pemancing.

Status masih merupakan atribut penting yang menandai maskulinitas, seperti tertuang dalam tulisan Pleck tentang peran dan identitas gender laki-laki (1995). Temuan ini juga memperkuat argumen Bereska (2003) bahwa memang maskulinitas hegemonis dan Male Gender Role Identity yang diusulkan oleh Connell (2005) dan Pleck (1995) sedikit sekali mengalami perubahan dan oleh karena itu, masih relevan. Selain itu, temuan dari kasus Bayu juga memperkuat argumen Stets dan Burke bahwa individu punya kebebasan untuk memilih atribut mana yang dirasa sesuai dengan dirinya dalam usahanya menegaskan identitas gender (1999).

Temuan menarik selanjutnya dikaitkan dengan konsepsi sportfishing sebagai suatu olahraga. Connell dan Messerschmidt mengungkapkan adalah mungkin suatu saat akan muncul sarana untuk 
menjadi lelaki dengan cara yang lebih beradab dan tidak opresif; dan ini mungkin akan menjadi hegemonis (2005). Studi ini menawarkan bahwa sportfishing mungkin menjadi jawaban atas prediksi tersebut, terutama dengan teridentifikasinya atribut-atribut yang termasuk dalam kategori ketiga dan keempat, yaitu pemberi nafkah dan pelindung. Pendapat ini didukung pula oleh argumen Messner bahwa maskulinitas hegemonis adalah konsep maskulinitas yang secara signifikan tercermin dalam bidang kajian olahraga (1992).

Temuan terakhir adalah mengenai atribut- atribut dalam kategori keempat: pelindung. Temuan ini menjadi amat menarik karena mengandung kontras. Atribut-atribut dalam kategori empat sebenarnya lebih merupakan unsur yang biasanya ditemui dalam pengukuran femininitas, baik secara psikologis maupun sosiologis (Stets \& Burke 1999). Ini menunjukkan bahwa maskulinitas, yang merupakan serangkaian praktik, dapat berbeda tergantung dari relasi gender dalam wacana sosial tertentu (Connell \& Messerschmidt 2005). Dari sini dapat diindikasikan bahwa ada kemungkinan sportfishing tidak sepenuhnya maskulin, tetapi memiliki unsur feminin; atau dengan kata lain, androgin. Hal ini memperkuat argumen Davies bahwa individu dengan identitas gender tertentu mungkin mengadopsi aspek gender lain (2010, p. 22) dengan tujuan untuk menjadi lebih adaptif (Bem, dalam Harris 2005).

Adaptasi maskulinitas yang ditunjukkan dalam kegiatan sportfishing ini menandai apa yang disebut Demetriou sebagai masculine bloc (2001). Hal ini harus dilihat, pertama-tama, dari hubungan antara sportfishing dan teknik memancing konvensional; atau yang disebut sebagai, meminjam istilah Connell, maskulinitas hegemonis dan maskulinitas non-hegemonis. Teknik konvensional menjadi non-hegemonis karena tidak lagi efektif untuk mereproduksi dominasi patriarki. Hal ini ditunjukkan dengan partisipasi perempuan dalam kegiatan memancing konvensional. Meski memang masih didominasi oleh laki-laki, teknik konvensional lebih menyediakan ruang untuk partisipasi perempuan. Partisipasi ini merupakan wujud dari resistensi perempuan dalam usahanya untuk menggeser dominasi laki-laki dalam kegiatan memancing. Dengan kata lain, teknik memancing konvensional tidak lagi dapat meredakan ketegangan dalam relasi dua gender diatas, dan oleh karena itu, tidak lagi hegemonis (Connell \& Messerschmidt 2005). Mengantisipasi partisipasi perempuan tersebut, dunia memancing membutuhkan pola maskulinitas lain untuk tetap melanggengkan dominasi patriarki dalam praktiknya. Atribut- atribut maskulinitas dalam sportfishing, sebagaimana dijelaskan sebelumnya, dimunculkan sebagai jawaban atas kekosongan posisi hegemonis ini. Maskulinitas sportfishing yang terbagi dalam empat kategori tidak berdiri sendiri dalam proses formasinya, karena bagaimanapun juga, teknik sportfishing masih merupakan bagian dari kegiatan besar yang disebut memancing, demikian pula halnya dengan teknik konvensional. Unsur-unsur yang ada dalam teknik konvensional juga diadaptasi dan dapat dilacak jejaknya dalam praktik sportfishing. Inilah yang menjadikan sportfishing sebagai bentuk hybrid masculinities (Demetriou, 2001) yang lebih adaptif dalam melanggengkan patriarki.

Jadi jika dilihat dari relasi gender berdasarkan konsep maskulinitas hegemoni Connell, muncul relasi dalam gender dan relasi antar gender dalam praktik sportfishing sebagai konsep maskulinitas. Relasi dalam gender muncul antara sportfishing dan memancing konvensional, dan disebut sebagai hegemoni internal. Proses hegemoni internal ini telah dijelaskan dalam kontestasi antara sportfishing dan teknik konvensional dalam bagian awal bahasan ini. Sedangkan relasi antar gender muncul antara laki- laki dan perempuan dalam konteks sportfishing, yang disebut sebagai 
hegemoni eksternal (Demetriou, 2001). Selain menyediakan limitasi fisiologis bagi partisipasi perempuan, sportfishing juga menyediakan limitasi psikologis dan ideologis dalam upayanya mengeksklusifkan kegiatan ini bagi laki-laki. Sportfishing memperoleh kapabilitas ini dengan mengatribusi tiga rezim gender sebagaimana diusulkan oleh Connell, yaitu pasar, negara, dan keluarga (Connell 1990,Connell \& Messerschmidt 2005, dan Demetriou,2001).

Dalam konteks sportfishing, rezim pasar bicara tentang bagaimana kegiatan ini diproduksi sebagai kegiatan yang maskulin, seperti yang dijelaskan di awal bab ini. Lelaki dalam hal ini memiliki patriarchal dividend (Connell 1996, p. 162) dari segi akses finansial. Konsepsi lelaki sebagai breadwinner mengharuskan mereka bekerja dan mencari nafkah, dan oleh karena itu memiliki lebih banyak akses terhadap sumber-sumber finansial. Harga piranti sportfishing yang relatif mahal, yang menyebabkannya hanya mampu dijangkau oleh mereka yang memiliki akses finansial lebih, merupakan wujud praktis dari rezim ini.

Rezim negara bicara tentang kekuasaan yang diinstitusionalisasi. Dalam hal ini, sportfishing menikmati warisan dari konsepsi memancing yang secara umum dipahami sebagai kegiatan lakilaki. Oleh karena ideologi tersebut, pemegang-pemegang kekuasaan dalam institusi memancing pun adalah laki-laki. Dari tiga komunitas pemancing yang menjadi subjek penelitian ini, seluruh pengurus dan pengelolanya adalah laki-laki. Di sisi sebaliknya, ideologi tersebut juga bekerja dari dalam perempuan sendiri untuk menjauhkan mereka dari kegiatan sportfishing. Contoh sederhana adalah konsepsi bahwa perempuan harus selalu tampil terawat dan sempurna (Wolf 1992). Konsepsi ini akan menjauhkan perempuan dari kegiatan memancing yang mengharuskan mereka berinteraksi dengan panas matahari, air kotor, ikan, dan fasilitas yang minimal saat memancing.

Perempuan juga dijauhkan dari sportfishing lewat rezim keluarga. Perempuan memiliki peran nurturing dalam keluarga, menunjukkan kehangatan, afeksi dan kepekaan emosional terhadap anggota keluarga yang lain. Yang menarik disini, seperti telah ditunjukkan sebelumnya, peran tersebut ternyata telah diatribusi oleh laki-laki; baik dalam sosok seorang ayah yang memperkenalkan dan mengajari anaknya memancing, maupun sosok pemancing yang mempraktikkan tangkap-lepas demi melestarikan populasi ikan. Hal ini senada dengan pendapat Sarvan (1970) bahwa maskulinitas yang lebih feminin mulai menunjukkan ekskalasi. Melalui maskulinitas semacam inilah perempuan disubordinasi oleh laki- laki, dengan merebut dan menjalankan peran yang secara tradisional diatribusikan kepadanya. Laki-laki mengukuhkan dominasinya dengan menunjukkan bahwa ia mampu menjalankan peran perempuan, dan oleh karena itu, perempuan tidak lagi dibutuhkan.

Dengan menyatukan seluruh temuan dan pembahasan diatas, dapat disimpulkan bahwa sportfishing merupakan bentuk maskulinitas baru yang menempati posisi sebagai maskulinitas hegemonis. Sportfishing meraih posisinya sekarang dengan mengatribusi maskulinitas nonhegemonis, dalam hal ini memancing konvensional, dan membentuk apa yang disebut Demetrieu sebagai - maskulinitas hibrida. Sportfishing juga memanfaatkan rezim gender untuk mengukuhkan dominasi laki-laki terhadap perempuan. Sportfishing bahkan, meminjam istilah Demetrieu, mengotorisasi elemen-elemen yang berbeda dan bahkan nampaknya berlawanan dengan maskulinitas; atau dalam kasus ini, femininitas untuk mereproduksi dominasi tersebut (Demetrieu 
2001).

\section{Simpulan}

Sebagai sebuah kegiatan yang maskulin, sportfishing mengandung atribut-atribut maskulinitas. Atribut- atribut ini dapat diamati dalam sikap, perilaku, dan pendapat yang dikemukakan oleh para pemancing saat mereka melakukan kegiatan tersebut maupun saat berinteraksi dengan sesama pemancing. Atribut-atribut yang muncul dikelompokkan dalam 4 kategori, yaitu Unjuk Keahlian, Kemampuan Fisik, Pemberi Nafkah, dan Pelindung. Dari 24 atribut yang terbagi dalam 4 kategori tersebut, hanya satu atribut yang ternyata tidak muncul dalam konteks pemancing di Indonesia, yaitu atribut Superman. Hal ini menunjukkan bahwa konsepsi maskulinitas Indonesia relative berbeda dengan konsepsi maskulinitas di Barat. Lebih lanjut lagi, ketidakmunculan atribut Superman, disertai dengan kasus pengalihan atribut yang ditunjukkan oleh Bayu serta atribut dalam kategori Pelindung yang sarat akan unsur femininitas, menunjukkan bahwa sportfishing adalah suatu bentuk maskulinitas hibrida yang disebut Demetriou sebagaai masculinity bloc (2001). Jenis hibrida ini menggantikan posisi memancing konvensional yang tidak lagi mampu mereproduksi dominasi patriarkal, dan oleh karena itu, menjadi hegemonic masculinity dalam konteks memancing.

Sportfishing sebagai bentuk maskulinitas yang hegemonis dapat dimanfaatkan sebagai media kampanye untuk mempopulerkan praktik tangkap- lepas. Dengan mempopulerkan sportfishing yang berorientasi pada proses, maka penggiat kegiatan memancing diharapkan dapat mengesampingkan hasil, yaitu ikan itu sendiri. Dengan begitu, mereka akan lebih bersedia mempraktikkan tangkap-lepas.

\section{Daftar Pustaka}

Aas, Oystein, 2002, "The Next Chapter: Multicultural an Cross-Disciplinary Progress in Evaluating Recreational Fisheries," dalam Pitcher, Tony J. dan Charles E. Hollingworth. Oxford: Blackwell Science (Eds),.Recreational Fisheries: Ecological, Economic and Social Evaluation.pp. 252-263

Adams, Ali, et.al., 2010, "Establishing and Challenging Masculinity: The Influence of Gendered Discourses in Organized Sport,"Journal of Language and Social Psychology. Vol 29, <http://jls.sagepub.com/content/29/3/278> diakses 27 Juni 2012

Beehler, Gregory P. et.al., 2002, "Identification of Sport Fish Consumption Patterns in Families of Recreational Anglers through Factor Analysis."Environmental Research Section A. November 2011

Bishop, Richard C. dan Karl C. Samples, 1980, "Sport and Commercial Fishing Conflicts: A Theoretical Analysis," dalam Journal of Environmental Economics and Management. 7, pp. 220-233.

Bourdieu, P., 2001, Masculine Domination. Palo Alto: Stanford University Press.

Bryson, L., 1987, "Sport and the Maintenance of Masculine Hegemony." Women's Studies International Forum. 10. pp. 349-360.

Butler, Judith, 1999, Gender Trouble. London: Routledge.

Coakley, Jay, 2009, Sports in Society: Issues and Controversies. Edisi ke-10. New York: McGrawHill.

Connell, Robert W., 1996, "New Directions in Gender Theory, Masculinity Research and Gender Politics," dalam Ethnos, Vol. 61, pp. 161-162. 
Connell, Robert W., 2005, Masculinities. Edisi ke-2.

Los Angeles: University of California Press.

Connell, R. W., \& Messerschmidt, J. W., 2005. "Hegemonic Masculinity: Rethinking the Concept," dalam Gender \& Society, Vol. 19, pp. 829-859.

$<$ http://gas.sagepub.com/content/19/6/829> diakses 23 Maret 2012

Cooke, Steven J. dan Ian G. Cowx. "Contrasting Recreational and Commercial Fishing: Searching for Common Issues to Promote Unified Conservation of Fisheries Resources and Aquatic Environments," dalam Biological Conservation, Vol. 128,pp. 93-108.

<www.elsevier.com/locate/biocon> diakses 17 November 2011

Davies, Sharyn G., 2010, Gender Diversity in Indonesia: Sexuality, Islam and Queer Selves. Oxon: Routledge.

Demetriou, Demetrakis Z., 2001, "Connell's Concept of Hegemonic Masculinity: a Critique." Dalam Theory and Society, Vol. 30, Kluwer Academic Publishers. pp. 337-361.

Good, Glenn E, et al., 1994, "Masculinity Research: a Review and Critique," dalam Applied \& Preventive Psychology 3. Cambridge: Cambridge University Press. pp. 3-14.

Harris, Ian M., 2005, Messages Men Hear: Constructing Masculinities. London: Taylor and Francis, Ltd.

Haywood, Chris dan Mairtin Mac an Ghaill., 2003, Men and Masculinities: Theory, Research and Social Practice. Buckingham: Open University Press.

Kerr, J.H., et al. "Motivation and Level of Risk in Male and Female Recreational Sport Participation," dalam Personality and Individual Differences, Vol.. 37, pp. 12451253. <www.elsevier.com/locate/paid> diakses 27 Juni 2012

Lippa, Richard A., 2005, Gender, Nature and Nurture.Edisi ke-2. New Jersey: Lawrence Erlbaum Associates, Inc.

Lippa, R. dan Arad, S., 1999, "Gender, Personality, and Prejudice: The display of authoritarianism and social dominance in interviews with college men and women," dalam Journal of Research in Personality, Vol. 33, pp. 463-493.

Louie, Kam dan Morris Low, ed., 2005, Asian Masculinities: The Meaning and Practice of Manhood in China and Japan. London: Routledge Curzon.

Messner, M. A., 1992, Power at Play: Sports and the Problem of Masculinity. Boston: Beacon.

Moffit, T. E., et.al., 2001, Sex Differences in Antisocial Behavior. Cambridge: Cambridge University Press.

$\mathrm{Ng}$, Chirk Jenn, et.al., 2008, "What do Asian Men Consider as Important Masculinity Attributes? Findings from the Asian Men's Attitudes to LifeEvents and Sexuality (MALES) Study," dalam Journal of Men's Health. 5. pp. 350-355.

Pitcher, Tony J. dan Charles E. Hollingworth. 2002, "Fishing for Fun: Where's the Catch?" dalam Pitcher, Tony J. dan Charles E. Hollingworth (Eds.) Recreational Fisheries: Ecological, Economic and Social Evaluation. Oxford: Blackwell Science. pp. 1-16.

Policansky, David., 2002, "Catch-and-Release Recreational Fishing: A Historical Perspective," dalam Pitcher, Tony J. dan Charles E. Hollingworth (Eds.) Recreational Fisheries: Ecological, Economic and Social Evaluation. Oxford: Blackwell Science. pp. 74-94.

Pronger, B., 1990, The Arena of Masculinity: Sports, Homosexuality, and the Meaning of Sex. New York, NY: St. Martin's Press

Reeser, Todd W., 2010, Masculinities in Theory: An Introduction. Oxford: John Wiley \& Sons Ltd.

Reiss, Peter. et.al., 2003, "Catch and Release Fishing Effectiveness and Mortality," Acute Angling, Inc., Web diakses 17 November 2011.

Schultz, Ken., 2010, Essensials of Fishing: the Only Guide You Need to Catch Freshwater and Saltwater Fish. New Jersey: John Wiley \& Sons, Inc. 
Stets, Jan E. dan Peter J. Burke., 1999, "Femininity/Masculinity."dalam Borgatta, Edgar F. dan Rhonda J. V. Montgomery (Eds.) Encyclopedia of Sociology. Edisi Revisi. New York: Mcmillan. pp. 997-1005.

Sugiyono. 2011, Metode Penelitian Kuantitatif, Kualitatif dan R\&D. Edisi ke-13. Bandung: Alfabeta,

Symes, David dan Ellen Hoefnagel. 2010, "Fisheries Policy, Research and the Social Sciences in

Europe: Challenges for the $21^{\text {st }}$ Century,"dalam Marine Policy, Vol. 34, pp. 268-275. <www.elsevier.com/locate/marpol> diakses 17 November 2011.

Thomas, J. R. dan French, K. E., 1985, "Gender Differences Across Age in Motor Performance: a Meta-Analysis,"dalam Psychological Bulletin, Vol. 98, pp. 260-282.

Timmers, Molly. "The Coral Triangle and Marine Biodiversity".oceanexplorer.noaa.gov.

<oceanexplorer.noaa.gov/okeanos/exploration s/10index/ background/biodiversity/biodiversity.html>. diakses 24 November 2011.

Verma, Ravi K., dan Vaishali S. Mahendra. 2008, "Construction of Masculinity in India: A Gender and Sexual Health Perpective,"dalam Journal of Family Welfare, Vol. 50, pp. 71-78.

Wolf, Naomi., 1992, The Beauty Myth: How Images of Beauty Are Used Against Women. New York: Anchor 